\title{
A Study on "Judaism" of the Third-Generation Jewish American Writers
}

\section{Zhao Xinliang}

School of Foreign Studies, Yangtze University, Hubei, 434023 PRC China

Received: 6 Oct 2020; Received in revised form: 13 Nov 2020; Accepted: 17 Nov 2020; Available online: 22 Nov 2020

C2020 The Author(s). Published by Infogain Publication. This is an open access article under the CC BY license

(https://creativecommons.org/licenses/by/4.0/).

\begin{abstract}
In view of the researches of theme, "Judaism" of the third-generation Jewish American writers, scholars at home and abroad have made some researches. Rather, the studies are not mature and systematic. Most scholars merely focus on a piece of work of those writers or a single theme. At present, scholars mainly carry out researches on the theme of Judaism from the following aspects: returning to Judaism, Judaism identity anxiety, as well as the consultation between orthodox Judaism and feminist. Analyzing and summarizing researches from the above three aspects will promote further study to some extent.
\end{abstract}

Keyword-Third-generation Jewish American writers; Judaism; identity anxiety; the consultation between orthodox Judaism and feminist.

\section{INTRODUCTION}

Judaism and Jewish culture have strong ties with Jews. Most works of literature written by Jewish American literature center around Judaism, feminism and Holocaust. Especially, third-generation Jewish American writers such as Allegra Goodman, Cynthia Ozick, Nathan Englander and so on, tend to focus on Judaism, which brings new life to Jewish American culture.

In this paper, I will focus on the following three aspects, third-generation Jewish returning to Judaism, identity anxiety on Judaism and the reconciliation between orthodoxy and feminism. By introspecting protagonist's growth course in these works of third generation Jewish writers, I am expecting to find out their attitude towards Jewishness.

\section{RETURN TO JUDAISM}

Most third-generation Jewish American writers attempt to focus on the theme of "returning to Judaism". It is different from the theme of immigration adjustment presented by the first-generation writers and the marginalization of Jews concerned by the second-generation writers in the United States (Furman, 1997). Three years later, in another paper, he has noticed the changes of themes in contemporary American Jewish writers' works, and expected that this new generation will continue to pay attention to Jewish culture and create the concept of "Jewish American Literature" (Furman,2000). The theme of "Returning to Judaism" in American Jewish literature can be divided into two categories: "One is to praise God and the redemptive power of the Jewish community represented by Ozick, who firmly believe in the establishment of a Jewish-centered American literature with English as their mother tongue; the other is to question God's relationship with Israel, God's relationship with Judaism and the nature of people." (Zhang, 2014)

In the novel, For the Relief of Unbearable Urges by 
Nathan Englander, Binyamin's wife, Chava, is a highly abstract symbol of Judaism and stands for complex Jewish cultural tradition. Binyamin is in the mood to work close with his wife, yet disturbed by her vague attitude, which symbolize Binyamin's attitude towards Judaism. Transformation from betraying his wife to reconciling with her symbolizes that Binyamin betrays Judaism and finally returns to Judaism and reaches reconciliation with it (Tang and Long, 2015). At the same time, Tang and Long (2015) also analyzed the theme of "Returning to Judaism" of Englander's another novel, "The Gilgul of Park Avenue". Charles feels his soul is possessed by Jewishness and becomes a Jew. He regulates his daily life in a Jewish way. His young American wife, Sue, suspects that Charles has gone into the devil. Charles tells his wife that he is just a Jew. He became a Jew spiritually, but still loved Sue deeply. The author emphasizes that during this period, Charles experienced the spiritual satisfaction brought by his returning to Judaism

In Tova Mirvis 's The Outside World, young people favor Judaism and the appeal of Jewishness is unfolded thoroughly (Middleton, 2009). The experience of "return to Jewishness" of this novel has been analyzed from three aspects. Firstly, the background and reasons of the hero's returning to Judaism are discussed. He finds that most American Jews have to erase Judaism in order to cater to the mainstream culture and gain their own living foundation. They continue to work on the Sabbath and eat food that is not suitable for Jewish traditions. However, his experience of studying in Israel makes him more firmly believe that they should study Talmud. Only by following the Jewish way of life can they attain spiritual tranquility. Secondly, the changes are made by the protagonist in order to return to Judaism. Over time, he has some cultural contradictions with his family. Finally, it elaborates the efforts made by the protagonist to return to Judaism and the compromise made to adapt to the mainstream culture of society. On the one hand, he should maintain his new identity. On the other hand, he should struggle with the mainstream cultural forces of "modernity" in the United States. In this process, the protagonist is no longer a religious extremist and has made some concessions and compromises (Ras,2005).
However, Ras (2005) analyzed "Joy Comes in the Morning" and explained the process of the hero's return to Jewishness psychologically. The hero, Lev is a scientist who is skeptical about religion and believes that everything would not last forever. He fled when he married his first girlfriend and later met D. Eborah, who guides Lev to go back to Judaism. Lev barely abides by Jewish tradition in his return to Jewishness, but contacts Judaism as much as possible in his life, comes to the synagogue more frequently, understands the connotation of Judaism, respects Jewish culture, and enjoys the happiness and satisfaction brought to him by observing Jewish culture. Thus, he achieves emotional and spiritual return.

In contrast, Ras (2005) discussed the theme of returning to Judaism in "Paradise Park" from another dimension. The protagonists in "The Outside World" and "Joy Comes in the Morning" are Jews and grow up in Jewish families. Unlike them, Sharon's American character enables her to adhere to departmentalism and embrace religion freely. During that period, she also faces the choice of different cultures and religions, isolated and lost. Finally, her American character of "quick decision" leads her to return from secular life to Jewishness.

Allegra Goodman has a strong sense of identification with Jewish traditional culture. She inherits and develops the literary traditions created by her predecessors. The Markowitz Family mainly expresses the different attitudes and conflicts of three generations of Jewish immigrants towards Judaism. Different from the first two generations, the third generation, Roth's granddaughter and son-in-law are both orthodox Jews, and their parents are puzzled by the strict observance of traditional Jewish rituals in their lives. Meanwhile, In Paradise Park, Judaism is the spiritual home to modern people who are spiritually empty and drifting like duckweeds (Wang, 2010). Yet the combination between the return to Judaism and slight feminism in some novels will puzzle readers.

In Mind-Body Problem, the heroine, Renee Feuer manages to release from Judaism. To her disappointment, the outside world is full of sexism. In the end, after realizing the reality of the world, she chooses to return to her husband and withdraw from adultery. Finally, she returns to Judaism (Budick, 1996). However, her 
sister-in-law strictly complies with the religious commitment heartfeltly without being disturbed by husband (Friedmann,1989).

\section{IDENTITY ANXIETY ON JUDAISM}

Jewish identity and confusion about their own Judaism are also deeply reflected in the works of the third-generation writers. Although characters in novel wear traditional Jewish clothes, their behaviors are not in line with Jewish culture, such as drinking whiskey, smoking marijuana, as well as men and women dancing traditional round dances (He, 2016). In The Pagan Rabbi, observing the Jewish law is regarded as a wall, which isolate the people from outside world. There are three main characters in the story, people inside the wall, outside the wall and above the wall being aware of the conflicts between Jewishness and the mainstream culture. These three aspects elaborate author's thinking on Jewishness identity anxiety (Wang, 2018).

\section{THE RECONCILIATION BETWEEN ORTHODOXY AND FEMINISM}

Because of the gender difference, the female is responsible for mothering, and domesticity. In this process, they are more likely to affirm their autonomy(Kaufman DR, 1985). There is some complex relationship between feminism and psychoanalysis (Barry, 2017). It is not difficult to find out that some female characters manage to imagine their free and happy life, such as Elizabeth in Kaaterskill Fall. Elizabeth lives in an orthodox Jewish community. Her religious lifestyle makes her stay far away from the secular life. She has to do housework and other trivial things so that she cannot communicate with the outside world except chatting with her neighbors and reading secular novels. Nevertheless, she has always been longing for secular life and looking to create her own new life----opening stores, running parties and striving to pursue the life she yearns for. Gradually, she does not stick to the traditional roles of women in orthodox Judaism, and often doubts her role in the Jewish community. These are the manifestations of her deep feminist ideas. Finally, due to the more stringent restrictions of community, her desire to pursue a new life results in failure. Yet, she hardly gives up. Instead, she strives to coordinate the hidden feminist and traditional Jewish life (Grootenboer,2008). Elizabeth's desire to create a new life demonstrates the negotiation and constantly changing feminism, which is also a compromise between observing religious traditions and self-promotion(Omer-sherman, 2004). In addition, the contrast between faithful community and individuality can also be found in Kaaterskill Fall. Community is full of faith, restriction and orthodoxy, while she is rebellious and attracted by secular world. She has a romantic disposition and regards religion as a habit rather than a limit. Therefore, her attitude towards religion is a kind of reconciliation (Omer-sherman $\mathrm{R}$, 2004).

Rachel, the protagonist in the Romance Reader, is requested to wear thick stockings which means modesty and reputation for orthodox person. Meanwhile, In Preparing for Sabbath, when asking for a direction, Judith is advised to be buried just because of her shorts (Meyers, 2006). It is obvious that Orthodoxy restricts woman from modern situation. Mostly, there is collision between orthodoxy and feminism.

\section{CONCLUSION}

Although some achievements have been made in the study of Judaism at home and abroad, most of the works focus on the theme of a particular work. Generally speaking, there are relatively few studies on the theme of returning to Judaism and identity anxiety on Judaism by the third-generation American Jewish writers. Apart from the conciliation between orthodox Judaism and feminism, much more research is urgently needed on the theme of returning to Judaism and identity anxiety on Judaism.

\section{REFERENCES}

[1] Barry, P. (2017). Beginning theory: An introduction to literary and cultural theory. Oxford university press.

[2] Budick, E. M. (1996). Feminism, Jewish History, and the Holocaust in Rebecca Goldstein's " Mind-Body Problem

". Contemporary Jewry, 66-78.

[3] Friedmann, T. (1989). Back to orthodoxy: The new ethic and ethnics in American Jewish Literature. Contemporary 
Jewry, 10(1), 67-77.

[4] Furman, A. (2000). Is the Jew in Vogue?. Tikkun, 15(6), 29-52.

[5] Furman, A. (1997). Israel Through the Jewish-American Imagination. Melus, 25(1),234

[6] Kaufman, D. R. (1985). Women who return to Orthodox Judaism: A feminist analysis. Journal of Marriage and the Family, 47(3),543-551.

[7] Grootenboer, G. (2008). " Outsider Insiders": Female Jewish Orthodox Protagonists and the Outside World (Master's thesis).

[8] Meyers, H. (2006). Jewish Gender Trouble: Women Writing Men of Valor. Tulsa Studies in Women's Literature, 25(2), 323-334.

[9] Middleton, D. J. (2009). Religion and literature's unfinished story. Religion \& literature, 41(2), 149-157.

[10] Omer-Sherman, R. (2004). Orthodox Community and Individuality in Allegra Goodman's" Kaaterskill Falls". Religion \& literature, 36(2), 75-97.

[11] Omer-Sherman, R. (2004). Tradition and Desire in Allegra Goodman's" Kaaterskill Falls". Melus, 29(2), 265-289.

[12] Ras, M. (2005). Diversity Within the Return to Religion: The Baal T'shuvah Phenomenon in Three Works of Recent Jewish American Fiction.

[13] He X. Y. (2016). On Jewishness of "What We Talk about When We Talk about Anne Frank". Journal of Lüliang University.6(03),24-26

[14] Wang,C.X. (2018).Identity Anxiety in "The Pagan Rabbi" by Cynthia Ozick. Literature Education. (01) :70-71

[15] Tang,W. \& Long,Y. (2011).Nathan Englander as One of the Third-Generation Jewish American Writers. Contemporary Foreign Literature. (3),26-33

[16] Zhang, J.P. (2014).Study on“Return"in Jewish American Literature. Journal of Chongqing Jiaotong University ( Social Sciences Edition).14(02),62-66 